\title{
DESAIN PENCACAH SERABUT KELAPA DENGAN PENGGERAK MOTOR LISTRIK
}

\author{
${ }^{(1)}$ Handoko Priono, ${ }^{(1)}$ Muhaammad Yusri Ilyas, ${ }^{(1)}$ Aditya Riska Nugroho, ${ }^{(1)}$ Dimas Setyawan, \\ ${ }^{(2)}$ Laili Maulidiyah, ${ }^{(1)}$ Rinasa Agistya Anugrah \\ ${ }^{(1)}$ Program Studi D3 Teknik Mesin, Program Vokasi, Universitas Muhammadiyah Yogyakarta \\ ${ }^{(2)}$ Program Studi Agroteknologi, Fakultas Pertanian, Universitas Muhammadiyah Yogyakarta \\ ${ }^{(1)}$ Email:handokopriono12@gmail.com \\ Jalan Brawijaya, Tamantirto, Kasihan, Bantul, Daerah Istimewa Yogyakarta
}

\begin{abstract}
Diesel Motor is a type of piston combustion motor commonly called Ignition Compression Engine Combustion Engine. The use of coconut fiber chopper machines using diesel drive engines in the market has not been able to increase consumer comfort and efficiency. Because this issue that emits $\mathrm{CO} 2$ and NOx also causes air pollution and noise emissions, tends to be relatively large and also requires intensive care that requires a lot of space and costs. This will renew the surrounding environment and allow user comfort and efficiency when running the machine. Therefore, it is necessary to have an efficient and optimal coconut fiber chopping machine by reducing noise so that it is not noisy and pollution free. The coconut fiber enumerator with an electric motor drive is an enumerator of coconut fibers with an electric motor as a solution for making household products and agricultural fertilizers to increase comfort and efficiency for consumers so as to increase economic value in the community. This research method begins with making a tool consisting of a study of literature, measuring each component of the tool consisting of a frame, eye drive, motor drive, filter and pulley and designing the design model. Trial on a no-load blade shaft rotation of $450 \mathrm{rpm}$. At the time of enumeration the shaft rotation is reduced to around 350-400 rpm and the linear velocity of the V-Belt is $3.9 \mathrm{~m} / \mathrm{s}$. From the coconut fiber chopper with an electric motor drive it causes low vibration, does not cause pollution nor is it efficient.
\end{abstract}

keywords: engine diesel, electric motor drive, design

Motor Diesel adalah jenis motor bakar piston yang biasanya disebut Motor Pembakaran Kompresi Compression Ignition Engine. Penggunaan mesin pencacah serabut kelapa menggunakan mesin penggerak engine diesel dipasaran belum mampu meningkatkan kenyamanan dan keefisienan konsumen. Hal ini dikarenakan yang mengeluarkan hasil pembakaran berupa $\mathrm{CO}_{2}$ dan $\mathrm{NOx}$ serta menimbulkan polusi udara dan polusi suara, berukuran relatif besar dan juga membutuhkan perawatan berkala sehingga membutuhkan ruangdan mengeluarkan biaya yang banyak. Hal ini akan memperburuk lingkungan sekitar dan mengganggu kenyamanan dan keefisienan pengguna saat mengoperasikan mesin tersebut. Karena itu dibutuhkan sebuah mesin pencacah serabut kelapa yang efisien dan optimal dengan mengurangi suara agar tidak bising dan bebas polusi. Pencacah serabut kelapa dengan penggerak motor listrik merupakan sebuah inovasi pencacah serabut kelapa dengan motor listrik sebagai solusi pembuatan produk rumah tangga dan pupuk pertanian untuk meningkatkan kenyamanan dan keefisienan bagi konsumen sehingga diharapkan dapat meningkatkan nilai ekonomi di masyarakat. Metode penelitian ini diawali dengan pembuatan alat terdiri dari studi literatur, mengukur tiap komponen alat yang terdiri dari rangka, mata pisau, motor penggerak, saringan dan puli lalu perancangan model desain. uji coba pada putaran poros mata pisau tanpa beban sebesar $450 \mathrm{rpm}$. Pada saat proses pencacahan putaran poros berkurang menjadi sekitar 350-400 rpm serta kecepatan linier V-Belt 3,9 m/s. Dari alat pencacah serabut kelapa dengan penggerak motor listrik menimbulkan getaran yang rendah, tidak menimbulkan polusi serta efisien. Kata kunci: engine diesel, penggerak motor listrik, desain

\section{PENDAhuluan}

Motor Diesel adalah jenis motor bakar piston yang biasanya disebut Motor Pembakaran
Kompresi Compression Ignition Engine (Putra, dkk., 2009). Pembakaran yang terjadi dalam ruang bakar dilakukan dengan cara 
menyemprotkan bahan bakar ke dalam silinder motor yang terisi dengan udara yang bertekanan dan bertemperatur tinggi, sebagai akibat dari proses kompresi. Penggunaan mesin ini belum mampu meningkatkan kenyamanan dan keefisienan konsumen karena menimbulkan getaran yang keras, polusi udara, polusi suara, mengeluarkan biaya yang banyak, serta ukuran mesin yang relatif besar. Hal ini dikarenakan mesin pencacah serabut kelapa menggunakan mesin penggerak engine diesel yang mengeluarkan hasil pembakaran berupa $\mathrm{CO}_{2}$ dan NOx serta mengeluarkan suara yang keras sehingga menimbulkan polusi udara dan polusi suara. Selain itu, mesin pencacah serabut kelapa yang menggunakan mesin penggerak engine diesel juga berukuran relatif besar dan juga membutuhkan perawatan berkala sehingga membutuhkan ruang dan mengeluarkan biaya yang banyak. Hal ini akan memperburuk lingkungan sekitar dan menggangu kenyamanan dan keefisienan pengguna saat mengoperasikan mesin tersebut. Karena itu dibutuhkan sebuah mesin pencacah serabut kelapa yang efisien dan optimal dengan mengurangi suara agar tidak bising dan bebas polusi. Pencacah serabut kelapa dengan penggerak motor listrik merupakan sebuah inovasi pencacah serabut kelapa dengan motor listrik bebas polusi sebagai solusi pembuatan produk rumah tangga dan pupuk pertanian serta merupakan hasil inovasi mesin pencacah serabut kelapa ada dipasaran untuk meningkatkan kenyamanan dan keefisienan bagi konsumen sehingga alat pencacah menjadi bergetar rendah, tidak berpolusi, hemat ruang dan juga hemat biaya. Oleh karena itu diharapkan dengan menggunakan penggerak mesin motor, mesin ini tidak mengeluarkan pembakaran gas, suara mesin yang kecil, desain yang relatif lebih kecil dan juga hanya membutuhkan perawatan perbaikan saja. Sehingga mesin ini menjadi mesin pencacah serabut kelapa ramah lingkungan yang simpel, ringan, relatif mudah dan hemat biaya. Mesin ini juga bekerja dengan menghasilkan serabut dengan beberapa varian yaitu kasar dan halus. Melihat kenyataan yang ada dilapangan penulis mencoba untuk menggantikan mesin pencacah serabut kelapa dengan penggerak engine diesel dengan merancang dan membuat mesin pencacah serabut kelapa dengan penggerak motor listrik yang dapat meningkatkan kenyamanan karena gentaran rendah, ramah lingkungan, efisien, serta hemat sehingga meningkatkan profit masyarakat.

\section{TINJAUAN PUSTAKA}

Syamsiro, dkk., (2016) melakukan pengujian mesin pencacah plastik pada penelitiannya dengan Rancangan pisau pencacah berjumlah 5 buah yang terdiri dari 3 buah pisau putar yang bergerak mengikuti putaran poros dan 2 buah pisau tetap yang menempel pada rangka mesin serta rancangan pisau pencacah berjumlah 5 buah yang terdiri dari 3 buah pisau putar yang bergerak mengikuti putaran poros dan 2 buah pisau tetap yang menempel pada rangka mesin saat proses pencacahan putaran poros berkurang menjadi sekitar 350-380 rpm. Hal ini diakibatkan oleh adanya pembebanan pada pisau-pisaunya untuk memotong plastik-plastik besar menjadi bentuk cacahan.

Penelitian lainnya menyebutkan bahwa dalam pembuatan mesin giling sampah plastik yang menggunakan jenis pisau potong Disc dari bahan lokal, dengan alasan tersedia dipasaran dan mudah memperolehnya serta tidak rumit dalam penggantian apabila sudah tumpul. Dengan bentuk pisau datar tersebut dan tersedia di pasaran akan membantu

pemilik mesin untuk melakukan penggantian secara cepat. Dudukan pisau potong langsung dipasangkan dengan poros yang langsung digerakkan oleh motor bensin 5,5 $\mathrm{Hp}$ dan banyak tersedia di pasaran. Mesin giling sampah plastik tersebut menggunakan energi yang berasal dari motor bensin 5,5 HP dan material masukan berupa sampah plastik, keluaran dari mesin tersebut berupa serpihan plastik. Dalam pengerjaan mesin tersebut mampu mengurai sampah plastik kering dengan ketebalan $0,3 \mathrm{~mm}$ sampai $2 \mathrm{~mm}$ (Yetri, dkk., 2016).

Anggraeni dan Latief, (2018) juga melakukan penelitian terhadap mesin pencacah plastik dengan tipe gunting dengan hasil penelitian mesin diesel yang digunakan dapat diganti dengan mesin penggerak lain selama daya yang ditransmisikan nilainya lebih dari 4,5 HP (3,3 kW). Mesin pencacah ini masih dapat dimodifikasi sesuai dengan kebutuhan. Transmisi pulley yang digunakan adalah tipe $\mathrm{V}$ alur tunggal dengan ukuran diameter penggerak $100 \mathrm{~mm}$ dan diameter pulley yang digerakkan $150 \mathrm{~mm}$. Daya yang dibutuhkan adalah 4,5 HP, sehingga digunakan mesin diesel dengan daya 5 
HP. Desain hopper meliputi safety factor dan kemudahan memasukkan sampah plastik yang akan dicacah.

\section{METODE PENELITIAN}

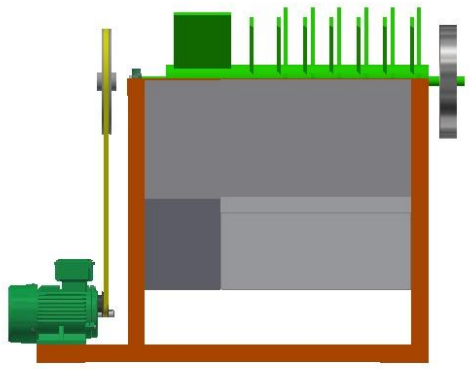

Gambar 1. Desain alat pencacah serabut kelapa dengan motor listrik tampak depan

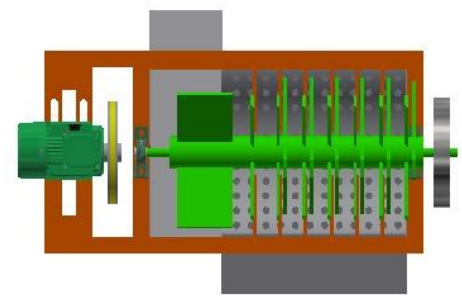

Gambar 2. Desain alat pencacah serabut kelapa dengan motor listrik tampak atas

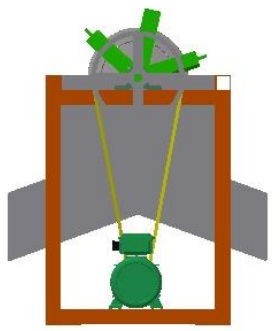

Gambar 3. Desain alat pencacah serabut kelapa dengan motor listrik tampak samping

Kegiatan pembuatan dan perancangan mesin pencacah serabut kelapa diperutuan bagi kawasan yang banyak ditumbuhi pohon kelapa. Mesin pencacah serabut kelapa dirancang menggunakan motor listrik, matrial masuKan berupa serabut kelapa dan keluaran dari mesin mesin pencacah serabut kelapa ini berupa: suara, getaran, cacahan serabut kasar dan lembut.

Perancangan mesin dilakukan per bagian dari keseluruhan unit mesin pencacah serabut kelapa untuk kemudian dilaukan perakitan (Napitupulu, dkk., 2011). Bagian-bagian unit tersebut antara lain:

- Unit pecacah serabut kelapa
- Unit rangka

- Unit keluaran serabut kelapa

- Unit motor peggerak

- Unit transmisi daya

Pembuatan komponen mesin dilakukan sesuai dengan rancangan yang sudah diuji dan sudah mempertimbangkan kemudahan mendapatan matrial, biaya yang semuarah mungkin, kemudahan pembuatannya dan kemudahan perawatanya.

Setelah pembuatan unit kemudian dilauakan penggabungan per bagian-bagian dan dilakukan pengujian mesin untuk memastikan mesin bekerja sesuai dengan rancangan. Pengujian menggunakan bahan serabut kelapa. Parameter pengujian meliputi kapasitas, ukuran cacahan dan meanisme kerja mesin. Jika mesin belum bekerja secara maksiaml maka dilakukan modifikasi dan berbaikan.

\section{HASIL DAN PEMBAHASAN}

A. Hasil

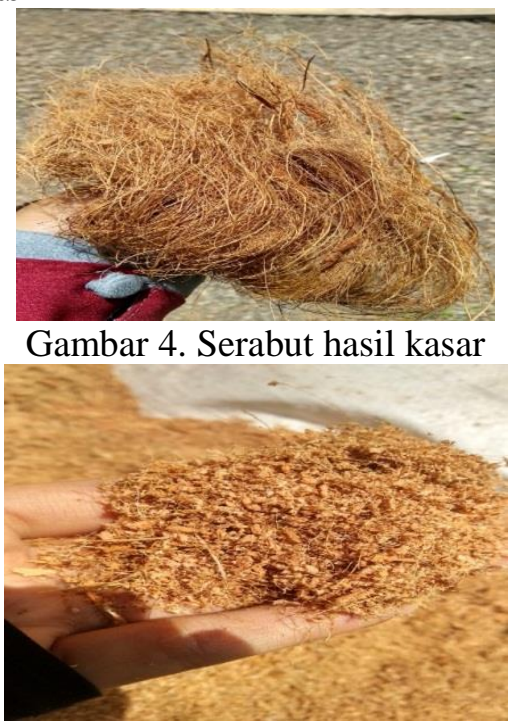

Gambar 5. Cocopeat hasil halus

Sabut kelapa ialah bahan berserat yang memiliki ketebalan sabut sekitar $5 \mathrm{~cm}$ dan merupakan bagian terluar dari buah kelapa. Sabut kelapa sendiri terdiri dari kulit ari, serat, dan sekam (dust). Berdasarkan keterangan UCAP (United Coconut Association of the Philipines), sebutir kelapa mengandung $0,4 \mathrm{~kg}$ sabut. Sementara sabut sendiri memiliki $30 \%$ serat. Dari serat sabut kelapa yang merupakan serat kasar menjadi bahan industri dan perdagangan, khususnya yang memakai bahan 
baku serat sabut kelapa yang tersebar di berbagai negeri penghasil kelapa. (Soekardi, 2012, di dalam Apriani, 2017).

Frick \& Koesmartadi, (1999) di dalam Apriani, (2017) mengatakan bahwa serat/serabut kelapa membentuk struktur kulit pembungkus tempurung kelapa. Serat kelapa bersifat tahan lama, kuat terhadap gesekan, tidak mudah patah, tahan air (tidak membusuk), tahan jamur dan hama, serta tidak dihuni oleh rayap maupun tikus.

Setelah dilakukan uji coba, mesin pencacah serabut kelapa yang dilakukan untuk mengetahui apakah mesin hasil rancangan dapat berfungsi sesuai dengan harapan. Kalau masih ada yang tidak sesuai maka dilakukan modifikasi dan perbaikan. Hasil uji coba menggunakan sampel serabut kelapa menunjukkan bahwa mesin dapat berfungsi sesuai yang diharapkan. Uji coba dilakukan pada putaran poros mata pisau tanpa beban sebesar $450 \mathrm{rpm}$. Pada saat proses pencacahan putaran poros berkurang menjadi sekitar 350$400 \mathrm{rpm}$. Dikarenaka adanya pembebanan pada pisau-pisau cacahan mesin serabut kelapa untuk memotong dan memisahkan serabut kelapa dengan cocopeat.

\section{B. Pembahasan}

Setelah melakukan desain dan penggabungan unit komponen, prinsip kerja dari mesin pencacah serabut kelapa ini dengan menggerakkan pisau putar menggunakan motor listrik. Daya dari mesin ini ditransmisikan menggunakan puli dan sabuk. Sabut kelapa dimasukkan ke dalam mesin melalui corong masukan hingga mengenai pisau pencacah. Cacahan serabut kelapa kemudian keluar melalui saringan bawah dan corong keluaran.

Ada beberapa komponen yang dimiliki mesin pencacah ini. Adapun komponenkomponen tersebut adalah sebagai berikut:

\section{a. Rangka}

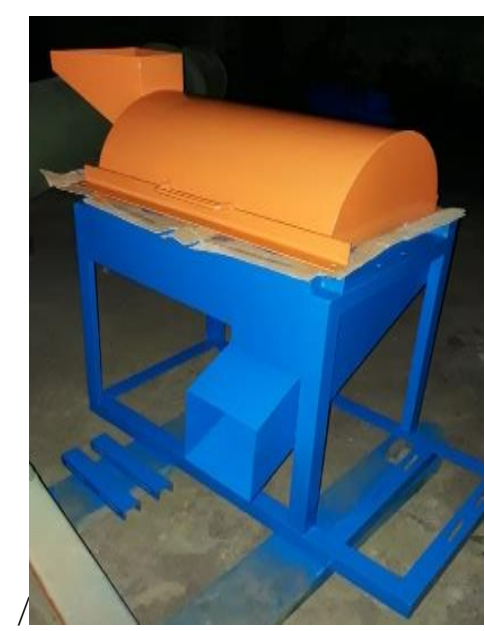

Gambar 6. Rangka

Rangka berfungsi sebagai penyangga dan tempat dipasangnya komponen-komponen mesin seperti motor listrik, pisau pencacah, bantalan dan casing atas. Desain rangka dirancang untuk dapat menahan beban komponen-komponen tersebut.

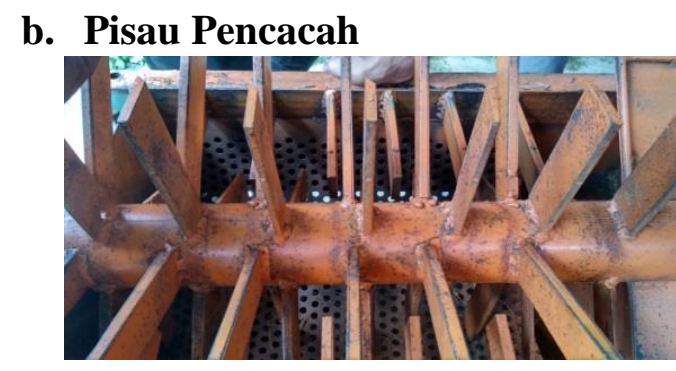

Gambar 7. Pisau pencacah

Rancangan pisau pencacah menggunakan dua jenis mata pisau,yaitu mata pisau diam (menempel pada rangka) dan mata pisau yang berputar mengikuti putaran poros.Pisau putar berfungsi untuk memisahkan dan mengurai serabut kelapa yang dimasukkan dari corong masukan. Proses pencacahan plastik terjadi pada saat posisi pisau putar dan pisau tetap berhadapan atau berhimpit. Pisau putar ditempatkan pada dudukan yang dipasang pada poros pemutar. Poros ini ditopang oleh 2 buah bantalan pada sisi kiri dan kanan poros. Pada ujung poros dipasang puli sebagai pemutar poros dari hasil daya putaran motor listrik. Pemilihan material untuk pisau ini sangat penting karena di bagian inilah terjadi proses pemotongan, sehingga keuasan cepat terjadi. Penggunaan per daun dari kendaraan berat bisa 
jadi alternatif pilihan yang mudah dan tepat untuk pembuatan pisau ini.

\section{c. Saringan Cacahan}

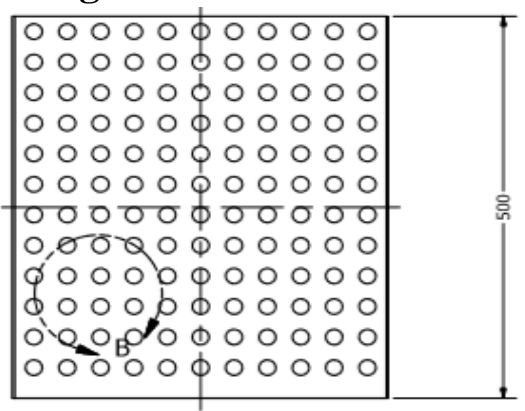

Gambar 8. Saringan alat

Saringan ini berfungsi untuk memfilter uraian serabut kelapa dan cocopeat yang akan keluar dari mesin.Desain saringan dibuat dengan diameter lubang sebesar $1 \mathrm{~cm}$ dan jarak antar lubangnya $3 \mathrm{~cm}$ cacahan plastik keluar dari mesin.

\section{d. Motor listrik}

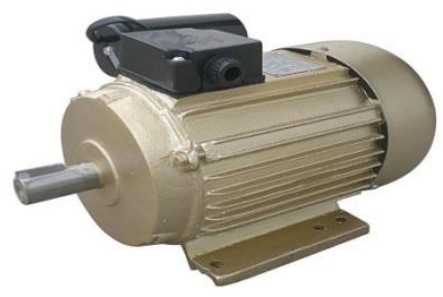

Gambar 9. Motor listrik

Motor listrik adalah komponen standar pada sistem penggerak yang digunakan pada mesin pencacah serabut kelapa.

\section{e. Puli}

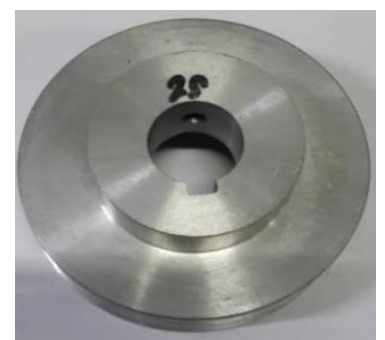

Gambar 10. Puli

Puli merupakan suatu elemen mesin yang berfungsi sebagai tempat dudukan sabuk atau penggerak sabuk yang digunakan untuk menyalurkan daya dan putaran dari motor listrik ke poros mata pisau. Untuk perencanaan ini menggunakan puli dan bebera yang harus diperhatikan dalam perencanaan puli. Perencanaan puli dan sabuk - V harus mengperhitungkan terlebih dahulu. Rumus perhitungn puli dan sabuk $-\mathrm{V}$ adalah menentukan perbandingan tranmisi, kecepatan tranmisi dan kecepatan sabuk. Rumus perhitungan adalad sebagai berikut:

\section{Memutar Kecepatan Poros Pisau:}

Sutowo, dkk., (2010) untuk menghitung kecepatan putar poros pisau sebagai berikut:

$$
\frac{n_{1}}{n_{2}}=\frac{D_{p}}{d_{p}}
$$

Dimana:

$\mathrm{n}_{1=\text { Putaran }}$ motor listrik

$\mathrm{n}_{2=\text { Putaran }}$ poros mata pisau

$\mathrm{D}_{\mathrm{p}=\text { Diameter }}$ puli poros mata pisau

$\mathrm{d}_{\mathrm{p}=\text { Diameter puli }}$ motor listrik

Dalam perencanaan mesin pencacah serabut kelapa juga menggunakan rumus seperti rumus di atas

$\frac{1.800}{n_{2}}=\frac{355,6}{88.9}$

$355,6 \times \mathrm{n}_{2}=1.800 \times 88,9$

$\mathrm{n}_{2}=\frac{1.800 \times 88.9}{355,6}$

$\mathrm{n}_{2}=450 \mathrm{Rpm}$

Hasil pengujian fungsional pada mesin pencacah serabut kelapa memiliki fungsi untuk mengetahui desain yang sesuai dengan alat nyata. Motor listrik berputar pada $1.800 \mathrm{rpm}$ dan poros pisau berputar pada $450 \mathrm{rpm}$.

\section{Kecepatan Linier V-belt}

$\mathrm{V}=\frac{\pi \times \mathrm{d}_{\mathrm{p}} \times \mathrm{n}_{1}}{60 \times 1000}$

$V=\frac{3.14 \times 88,9 \times 1.800}{60 \times 1000}=8,4 \mathrm{~m} / \mathrm{s}$

Dengan putaran kecepatan motor listrik $1.800 \mathrm{rpm}$, kecepatan linier V-Belt yang menghubungkan kedua puli, puli motor listrik dan puli poros mata pisau, dihitung $3,9 \mathrm{~m} / \mathrm{s}$.

Pada penelitian Sugiyanto dan Trisnowati, (2018) tentang Rancang Bangun Mesin Perajang Kerupuk Jengkol menunjukkan bahwa Mesin Pemotongan Gendar Kerupuk Jengkol yang dirancang dengan penggerak motor listrik 
dengan putaran motor $1450 \mathrm{rpm}$ direduksikan dengan sistem transmisi Vbelt serta dirancang dengan jumlah pisau 3 buah bekerja dengan baik. Hasil yang didapatkan mesin tersebut adalah 10 batang gendar kerupuk rambak seberat $5 \mathrm{~kg}$, proses pemotongan membutuhkan waktu 10 menit, karena proses pemotongan dengan menggunakan mesin.

\section{KESIMPULAN}

Desain dan fabrikasi mesin pencacah serabut kelapa dengan motor listrik merupakan sebuah inovasi untuk memenuhi kebutuhan prodeusen kerajinan dan pupuk pertanian. Desain dirancang dengan membuat bagianseperti unit rangka, unit keluaran serabut kelapa, unit motor peggerak dan unit transmisi daya dengan uji coba pada putaran poros mata pisau tanpa beban sebesar $450 \mathrm{rpm}$. Pada saat proses pencacahan putaran poros berkurang menjadi sekitar 350-400 rpm serta kecepatan linier V-Belt 3,9 m/s. Dari alat pencacah serabut kelapa dengan penggerak motor listrik menimbulkan getaran yang rendah, tidak menimbulkan polusi serta efisien.

\section{UCAPAN TERIMAKASIH}

1. Kementerian RISTEKDIKTI, karena telah memberikan dana hibah dalam Program Kreativitas Mahasiswa bidang Penerapan Teknologi (PKM-T)

2. Rinasa Agistya Anugrah, S.Pd., M.Eng., selaku dosen pembimbing yang telah membantu mempersiapkan dan membimbing dalam serangkain program PKM-T serta publikasi dalam jurnal ini.

\section{Daftar Pustaka}

Anggraeni, N. D., \& Latief, A. E. (2018).

Rancang Bangun Mesin Pencacah Plastik Tipe Gunting. Jurnal Rekayasa Hijau, 2(2).

Apriani, Enda. (2017). Analisa Pengaruh Variasi Komposisi Bahan Limbah dari Serat Kelapa Muda, Batang Pisang dan Kertas Bekas Terhadap Kekuatan Bending Sebagai Papan Komposit. Jurnal Engine Vol.1 No.2, Nopember 2017, pp no 38-46.
Frick, H., \& Koesmartadi, C. (2012). Ilmu Bahan Bangunan (Cetakan ke-10). Penerbit Kanisius, ISBN 978-979-672444-4.

Napitupulu, R., Subkhan, M., \& Nita, L. D. (2011). Rancang bangun mesin pencacah sampah plastik. J Manutech, 3(1), 1-5.

Putra, N., Koestoer, R.A., Adhitya, M., Roekettino, A. \& Trianto, B. (2009). Potensi Pembangkit Daya Termoelektrik Untuk Kendaraan Hibrid. Makara teknologi, vol. 13, no. 2, pp. 53-8.

Soekardi, Y. (2012). Pemanfaatan \& Pengolahan Kelapa. Yrama Widya, ISBN 978-979-077-427-8.

Sugiyanto dan Trisnowati, Juni. (2018). Rancang Bangun Mesin Perajang Kerupuk Jengkol Untuk Meningkatkan Pendapatan UKM. Jurnal Engine Volume 2 No. 2.

Sutowo, Cahya, and Ery Diniardi. (2010). "Perencanaan Mesin Penghancur Plastik Kapasitas $30 \mathrm{Kg} / \mathrm{Jam}$," Sintek Jurnal Vol 4, No 2:4.

Syamsiro, M., Hadiyanto, A. N., \& Mufrodi, Z. (2016). Rancang Bangun Mesin Pencacah Plastik Sebagai Bahan Baku Mesin Pirolisis Skala Komunal. Jurnal Mekanika dan Sistem Termal (JMST), 1(2), 43-48.

Yetri, Y., Sawir, H., \& Hidayati, R. (2016). Rancangbangun Mesin Pencacah Sampah Dan Limbah Plastik. In Seminar Nasional Pengabdian kepada Masyarakat (Vol. 1). 